\title{
Hubungan Stimulasi Bermain, Faktor Keluarga dan Faktor Anak dengan Perkembangan Balita di Wilayah Kerja Puskesmas Aur Duri Kota Jambi
}

\author{
Gusti Lestari Handayani ${ }^{1}$, Abbasiah ${ }^{2}$ \\ ${ }^{1,2}$ Nursing Departement of Health Polytechnic Jambi \\ Correspondence email: gusti_kia05@yahoo.com
}

\begin{abstract}
Abstrak. Perkembangan teknologi dan era globalisasi mempengaruhi banyak hal, termasuk jenis permainan anak, yang merupakan salah satu faktor yang mempengaruhi perkembangan anak. Perkembangan anak juga dipengaruhi oleh stimulasi dan psikologis. Rangsangan/stimulasi khususnya dalam keluarga, misalnya dengan penyediaan alat mainan, sosialisasi anak, keterlibatan ibu dan anggota keluarga lain akan mempengaruhi anak dlam mencapai perkembangan yang optimal. Permasalahan usia dini yang tidak terselesaikan dari sejak awal dapat menyebabkan permasalahan perkembangan pada masa selanjutnya, pengaruhnya tidak saja pada yang bersangkutan tapi pada lingkungan. Tujuan penelitian ini adalah untuk mengetahui hubungan sstimulasi bermain, faktor orang tua dan faktor anak dengan perkembangan balita di Wilayah Kerja Puskesmas Aurduru Kota Jambi. Rancangan penelitian adalah cross sectional dengan besar sampel minimal 31 anak dengan $\alpha=0,05$ dan $\beta=10 \%$. Lokasi penelitian adalah Wilayah Kerja Puskesmas Aur Duri Kota Jambi. Subjek penelitian adalah Balita diwilayah kerja Puskesmas Aurduri Kota Jambi. Hasil penelitian menunjukan ada hubungan signifikan jenis stimulasi bermain (P value 0,035$)$ dan Pola asuh (P value 0,000 ) dengan perkembangan balita. Perlu ditingkatkan perhatian pada pemberian alat permainan pada anak untuk sesuai dengan fungsi dan perkembangan anak. Dan Meningkatkan upaya pemantauan perkembangan balita melalui deteksi rutin balita sesuai usia.
\end{abstract}

Kata Kunci: Stimulasi bermain; perkembangan anak

\begin{abstract}
The development of technology and the era of globalization affect many things, including the type of children's play, which is one of the factors that influence children's development. Children's development is also influenced by stimulation and psychological. Stimulation, especially in the family, for example by providing toys, child socialization, involvement of mothers and other family members will influence the child in achieving optimal development. Early age problems that are not resolved from the beginning can lead to developmental problems in the future, the effect not only on the person concerned but on the environment. The purpose of this study was to determine the relationship of play stimulation, parent factors and child factors with the development of children under five in the Puskesmas Aurduri, Jambi City. The study design was cross sectional with a minimum sample size of 31 children with $\alpha=0.05$ and $\beta=10 \%$. The research location is the Aur Duri Health Center Work Area Jambi City. The subject of the research was Toddler in the working area of Aurduri Public Health Center in Jambi City. The results showed there was a significant relationship between types of play stimulation $(P$ value 0.035$)$ and parenting $(P$ value $0,000)$ with the development of toddlers. Attention needs to be paid to the provision of play equipment for children to suit the child's function and development. And Increase efforts to monitor the development of toddlers through routine detection of toddlers according to age.
\end{abstract}

Keywords: play stimulation; child development

\section{PENDAHULUAN}

Seiring proses tumbuh kembangnya. seorang anak akan melalui tahap-tahap perkembangan dengan tugas perkembangan yang berbeda-beda, keberhasilan pencapaian suatu tugas perkembangan di suatu tahap akan membantu kelancaran tahap berikutnya. Hal ini menunjukkan bahwa anak dikatakan berkembang secara normal apabila anak dapat menyelesaikan tugas-tugas yang harus dijalaninya pada masa tersebut. Sebaliknya apabila anak tidak mampu menyelesaikan tugas-tugas yang harus dijalaninya maka dapat dikatakan bahwa anak mengalami hambatan dalam perkembangannya. Secara umum, kesesuaian antara perkembangan anak dengan apa yang harus dicapainya dilihat melalui kematangan sosialnya.

Seorang anak dapat mengalami keterlambatan perkembangan dihanya satu ranah perkembangan saja atau dapt pula dilebih dari satu ranah perkembangan. Keterlambatan perkembangan umum atau global development delay merupakan keadaan keterlambatan perkembangan yang bermakna pada dua atau lebih ranah perkembangan. Secara garis besar ranah perkembangan anak terdiri dari motorik kassar, motorik halus, bahasa/bicara, dan personal sosial/kemandirian. Sekitar 5-10\% anak mengalami keterlambatan perkembangan. Data angka kejadian keterlambatan perkembangan umum belum diketahui secara pasti, namun diperkirakan sekitar 1-3\% anak dibawah uisia 5 tahun mengalami keterlambatan perkembangan umum.

Tahap-tahap perkembangan anak salah satunya adalah fase bermain. Anak tidak dapat memisahkan antara bermain dan bekerja. Bermain adalah unsur yang penting untuk perkembangan anak baik fisik, emosional, mental, intelektual, kreativitas dan sosial. Fungsi bermain adalah 
untuk stimulasi pertumbuhan anak, namun sering terjadi kesalahan-kesalahan di dalam pemilihan alat permainan anak sehingga fungsi bermain pada anak menjadi tidak optimal (Soetjiningsih, 2005).

Stimulasi yang tepat akan merangsang otak balita sehingga perkembangan kemampuan gerak, bicara dan bahasa, sosialisasi dan kemandirian pada balita berlangsung optimal sesuai dengan umur anak. Deteksi dini penyimpangan tumbuh kembang perlu dilakukan untuk dapat mendeteksi secara dini adanya penyimpangan tumbuh kembang balita termasuk menindaklanjuti setiap keluhan orang tua terhadap masalah tumbuh kembang anaknya. Apabila ditemukan ada penyimpangan, maka dilakukan intervensi dini penyimpangan tumbuh kembang balita sebagai tindakan koreksi dengan memanfaatkan plastisitas otak anak agar tumbuh kembangnya kembali normal atau penyimpangannya tidak semakin berat. Apabila balita perlu dirujuk, maka rujukan juga harus dilakukan sedini mungkin sesuai dengan indikasi (Kemenkes RI, 2016)

Perkembangan anak juga dipengaruhi oleh stimulasi dan psikologis. Rangsangan/stimulasi khususnya dalam keluarga, misalnya dengan penyediaan alat mainan, sosialisasi anak, keterlibatan ibu dan anggota keluarga lain akan mempengaruhi anak dlam mencapai perkembangan yang optimal. Seorang anak yang keberadaannya tidak dikehendaki oleh orang tua atau yang selalu merasa tertekan akan mengalami hambatan didalam pertumbuhan dan perkembangan. Faktor lain yang tidak dapat dilepaskan dari pertumbuhan dan perkembangan anakadalah faktor sosial ekonomi. Kemiskinan selalu berkaitan dengan kekurangan makanan,kesehatan lingkungan (Tanuwijaya, 2003)

Kota Jambi memiliki jumlah penduduk terbesar yaitu 3.525.017 jiwa (17\%) dibandingkan dengan kabupaten kota lainnya di Propinsi Jambi, Jumlah anak dengan kelompok umur 0-4 tahun yaitu 322.571 jiwa $(9,18 \%)$ (Depkes, 2017), saat ini data yang didapatkan dari beberapa sumber hanya terbatas pada pertumbuhan dan penyakit yang dialami oleh anak dan balita namun data perkembangan anak belum dapat diperoleh.

\section{METODE}

Jenis penelitian ini adalah deskriptif analitik dengan rancangan cross sectional. Lokasi penelitian adalah Wilayah Kerja Puskesmas Aur Duri Kota Jambi. Pengambilan data dilakukan di Posyandu yang berlokasi di 3 (tiga) kelurahan yaitu Kelurahan Penyengat Rendah, Teluk Kenali dan Buluran Kenali yang dipilih secara acak. Pos yandu terpilih adalah Posyandu Akasia, Amanah dan Anggrek I. Penelitian dilaksanakan pada bulan Agustus - Oktober 2019. Data dikumpulkan dengan menggunakan kuisoner dan lembar observasi.

Besar sampel sebanyak 31 orang, Pemilihan sampel dengan cara proportionate stratifed random sampling yaitu suatu cara pengambilan sampel yang digunakan bila anggota populasinya tidak homogen yang terdiri dari kelompok yang homogen secara proporsional. Pada masing-masing posyandu terpilih dilakukan pengambilan data diambil secara proporsional dan didapatkan jumlah sampel yaitu: Posyandu Akasia 11 Balita, Posyandu Amanah 12 balita dan Posyandu Anggrek I 8 Balita. Subyek penelitian adalah ibu yang memiliki anak usia 2-5 tahun berada diwilayah kerja puskesmas Aur duri Kota Jambi.

Analisis Uji Statistik Variabel Penelitian Hubungan stimulasi bermain dan pola asuh dengan perkembangan balita di Wilayah kerja puskesmas Aurduri Kota Jambi adalah dengan menggunakan uji statistik Chi-Square.

\section{HASIL DAN PEMBAHASAN}

Gambaran wilayah penelitian: Puskesmas Aurduri berada di Kecamatan Telanaipura Kota Jambi memiliki 22 posyandu dengan wilayah kerja sebanyak 3 Kelurahan yaitu : Kelurahan Penyengat Rendah, Kelurahan Teluk Kenali dan Kelurahan Buluran Kenali. Jumlah balita usia 25 - 59 bulan untuk masing-masing kelurahan yaitu: 218 balita, 57 balita dan 88 balita.

Karakteristik responden yang diteliti yaitu usia anak, jenis kelamin, pendidikan orang tua, jenis stimulasi bermain dan pola asuh orang tua. Berdasarkan tabel 1 dapat diketahui bahwa sebagian besar responden (ibu balita) memiliki jenjang pendidikan paling tinggi SMA dengan kategori rendah sebanyak 23 orang (71.8\%). Sebagian besar jenis stimulasi yang didapatkan balita sesuai dengan umur yaitu 19 orang $(59,4 \%)$, pola asuh positif $23(71,9 \%)$ dan Perkembangan sesuai dengan umur 21 orang $(61,6 \%)$.

Tabel 1. Karakteristik Responden

\begin{tabular}{lcc}
\hline \multicolumn{1}{c}{ Karakteristik } & Frekuensi (n) & Persentase (\%) \\
\hline Posyandu & & \\
1. Akasia & 11 & 34.4 \\
2. Amanah & 14 & 43.8 \\
3. Aurduri 1 & 7 & 21.9 \\
Pendidikan Orang Tua & & \\
1. Tinggi & 9 & 28.1 \\
2. Rendah & 23 & 71.9 \\
Usia Anak & & \\
1. <3 tahun & 13 & 40.6 \\
2. $\geq 3$ tahun & 19 & 59.4 \\
Jenis Kelamin & & \\
1. Laki-laki & 9 & 28.1 \\
2. Perempuan & 23 & 71.9 \\
Jenis Stimulasi & & \\
1. Sesuai Umur & 19 & 59.4 \\
2. Tidak sesuai umur & 13 & 40.6 \\
Pola Asuh & & \\
1. Positif & 23 & 71.9 \\
2. Negatif & 9 & 28.1 \\
Perkembangan & & 65.6 \\
1. Sesuai umur & 21 & 34.4 \\
2. Keterlambatan & 11 & \\
\hline
\end{tabular}


Gusti Lestari Handayani dan Abbasiah, Hubungan Stimulasi Bermain, Faktor Keluarga dan Faktor Anak dengan Perkembangan Balita di Wilayah Kerja Puskesmas Aur Duri Kota Jambi

Hasil analisis hubungan pendidikan orang tua, jenis kelamin anak, usia naka, pola asuh dan jenis stimuasi dengan perkembangan balita dapt dilihat pada tabel 2

Tabel 2. Hasil Analisis Hubungan, Pola Asuh dan Stimulasi dengan Perkembangan Balita

\begin{tabular}{|c|c|c|c|c|c|c|}
\hline \multirow{3}{*}{ Variabel } & \multicolumn{4}{|c|}{ Perkembangan Balita } & \multirow{3}{*}{$\mathrm{P}$} & \multirow{3}{*}{ OR $95 \% \mathrm{CI}$} \\
\hline & \multicolumn{2}{|c|}{ Sesuai Usia } & \multicolumn{2}{|c|}{ Tidak sesuai usia } & & \\
\hline & $\mathrm{n}$ & $\%$ & $\mathrm{~N}$ & $\%$ & & \\
\hline \multicolumn{7}{|l|}{ Jenis stimulasi } \\
\hline - Sesuai Usia & 19 & 59,4 & 0 & 0 & 0,000 & 1,10 \\
\hline - Tidak Sesuai usia & 2 & 6,3 & 11 & 34.4 & & $0,96-1,23$ \\
\hline \multicolumn{7}{|l|}{ Pola Asuh } \\
\hline - Positif & 18 & 56,3 & 5 & 15,6 & 0,035 & 1,14 \\
\hline - Negatif & 3 & 9,4 & 6 & 18,8 & & $0,98-1,31$ \\
\hline
\end{tabular}

Hasil uji statistik diketahui $\mathrm{p}$ value 0,000 berarti $\mathrm{p}$ value $<0,05$ pada interval kepercayaan $95 \%$ dapat disimpulkan bahwa terdapat hubungan yang signifikan antara jenis stimulasi dengan perkembangan balita, begitu pula dengan pola asuh menunjukan hasil yang signifikan dengan $P$ value 0,035 .

\section{Pembahasan}

Istilah pengetahuan mengacu pada fakta, informasi, dan keterampilan yang diperoleh melalui pengalaman atau pendidikan dan pemahaman tentang suatu masalah atau fenomena sedangkan sikap mengacu pada sudut pandang, perspektif, reaksi, atau cara berpikir yang mantap tentang aspek pengasuhan atau perkembangan anak, termasuk peran dan tanggung jawab orang tua. Sikap mungkin terkait dengan kepercayaan budaya yang ditemukan dalam pengalaman umum. Praktik mengacu pada perilaku pengasuhan atau pendekatan pengasuhan anak yang dapat membentuk bagaimana seorang anak berkembang.

Secara umum, pengetahuan berhubungan dengan kognisi, sikap berhubungan dengan motivasi, dan praktik berhubungan dengan cara-cara menarik atau perilaku, tetapi ketiganya mungkin berasal dari sumber yang sama. Ketiga komponen ini bersifat timbal balik dan saling terkait secara teoritis, empiris, dan dua arah, saling menginformasikan satu sama lain. Misalnya, praktik terkait dengan pengetahuan dan sikap, dan sering melibatkan penerapan pengetahuan. Menurut teori modifikasi perilaku (Ajzen dan Fishbein, 2005), sikap seseorang sering menentukan apakah ia akan menggunakan pengetahuan dan mengubahnya menjadi praktik. Singkatnya, jika seseorang tidak percaya atau menghargai pengetahuan, ia cenderung untuk menindaklanjutinya. Apa yang dipelajari orang tua melalui praktik pengasuhan anak juga dapat menjadi sumber pengetahuan dan dapat membentuk sikap orang tua. Sikap parenting dipengaruhi juga oleh parenting self-efficacy, yang telah secara luas didefinisikan sebagai tingkat kepercayaan diri orang tua tentang kemampuan mereka untuk berhasil dalam peran parenting (Jones dan Prinz, 2005).
Pengetahuan pengasuhan, sikap, dan praktik dibentuk tidak hanya oleh satu sama lain tetapi juga oleh sejumlah faktor kontekstual, termasuk karakteristik anak-anak (misalnya, jenis kelamin, temperamen); pengalaman orang tua sendiri (mis., pengalaman masa kecil mereka sendiri) dan keadaan; harapan yang dipelajari dari orang lain, seperti keluarga, teman, dan jejaring sosial lainnya; dan sistem budaya. Dari relevansi khusus untuk penelitian ini, faktor-faktor kontekstual yang memengaruhi pengetahuan, sikap, dan praktik pengasuhan anak juga mencakup dukungan yang tersedia dalam komunitas yang lebih besar dan disediakan oleh lembaga, serta oleh kebijakan yang memengaruhi sifat dan ketersediaan layanan pendukung.

Teori perkembangan kognitif anak-anak di masa kanak-kanak, telah lama didasarkan pada karya Jean Piaget dan teori konstruktivisnya Jean piaget (2002) Sebagai komponen kunci dari karya Piaget, ia mengidentifikasi bahwa anak-anak berkembang melalui serangkaian tahap perkembangan kognitif saat mereka dewasa. Yang penting dalam pembelajaran anak usia dini. Perkembangan kognitif seorang anak melalui tahap praoperasi menghasilkan perubahan besar. Sepanjang tahap ini anak berkembang jauh dari egosentrisitas dan ketidakmampuan untuk berpikir logis, menuju pembelajaran yang lebih sosial dan kolaboratif. Sifat ingin tahu anak pada usia ini adalah kekuatan pendorong yang kuat.

Pada penelitian ini didapatkan hubungan yang signifikan antara jenis stimulasi bermaindan perkembangan anak balita dengan $p$ value 0,035 . Pada awal manusia dilahirkan belum bersifat sosial dalam arti belum meiliki kemampuan berinteraksi dengan orang lain. Kemampuan sosial anak diperoleh dari berbagai kesempatan dan pengalaman bergaul dengan orangorang dilingkungannya. Kebutuhan berinteraksi dengan orang lain telah dirasakan sejak enam bulan, disaat itu mereka telah mengenal manusia lain terutama ibu dan anggota keluarganya.

Perilaku anak atau dalam bahasa lain disebut juga temperamen menurut Chess \& Thomas dalam Wong (2005) mengidentifikasi sembilan variabel diantaranya adalah kemampuan anak dalam beradaptasi atau 
menyesuaikan rutinitas pada situasi yang baru. Anak dianggap mempunyai kemampuan adaptasi tinggi jika menunjukan kemampuan untuk dalam ketenangan dan sebaliknya kemampuan adapatasi rendah jika tidak mampu menyesuaikan diri dengan mudah.

Perilaku sosial anak-anak dalam perkembangan menuju kematangan sosial dapat diwujudkan dalam bentuk interaksi sosial diantaranya perilaku tidak sosial berupa pembangkangan (negativisme), agresivitas, bertengkar, mengejek, menggertak,mementingkan diri sendiri dan bisa berupa perilaku positive yaitu simpati, kerjasama, kemurahan hati, sikap ramah serta tidak mementingkan diri sendiri.

Bermain merupakan kegiatan yang dilakukan seseorang untuk memperoleh kesenangan, kegembiraan dan kepuasan tanpa memperhitungkan hasil akhir. Permainan memberikan pengaruh besar dalam mengembangakn kemampuan sosial anak, karena dengan permainan anak-anak dapat mengetahui peran dan fungsinya dalam kelompok, dengan permainan anak juga mempunyai teman banyak, membuat hidup anak lebih menarik dan menyenangkan. Melalui kegiatan bermain daya pikir anak terangsang untuk merangsang perkembangan emosi, perkembangan sosial dan perkembangan fisik.

Permainan akan mengembangkan dan memperuas sosialisasi anak sehingga anak dapat mengatasi persoalan yang akan timbul dalam hubungan sosial. Dengan sosialisasi akan berkembang nilai moral dan etik. Anak belajar yang benar dan yang salah serta bertanggung jawab atas kehendaknya. Bermain berfungsi juga sebagai alat untuk memupuk kesadaran diri anak karena dengan bermain anak akan sadar tentang kemampuan, kelemahan dan tingkah lakunya.

Alat permainan merupakan salah satu alat untuk menstimulasi pertumbuhan dan perkembangan anak. Jenis alat permainan balita akan merangsang kemampuan tertentu baik fisik, motorik kasar dan halus, bahasa serta tingkah laku sosial (Soetjiningsih, 2005).

Melalui kegiatan bermain, anak akan belajar memberi dan menerima. Bermain dengan orang lain (assosiative play) akan membantu anak mengembangkan hubungan sosial, belajar memecahkan masalah dari hubungan tersebut. Pada saat melakukan aktifitas bermain, anak belajar berinteraksi dengan teman, memahami lawan bicaranya dan belajar tentang nilai sosial yang ada pada kelompoknya. Hal ini adalah tahapan awal bagi anak usia toddler dan prasekolah untuk meluaskan aktifitas sosialnya diluar lingkungan keluarga.

Bermain memiliki fungsi untuk meningkatkan perkembangan sensorimotor, intelektual, sosial dan moral, kreativitas, kesadaran diri dan nilai terapeutik. Jenis permainan berbeda untuk masing-masing fungsi, untuk perkembangan sosial pada anak usia pra sekolah dianjurkan untuk bermain rumah mainan, boneka, mobilmobilan, peralatan dokter dan perawata, alat berdandan
(Wong, 2005). Dalam penelitian ini terlihat bahwa jenis permainan anak lebih banyak permainan yang mendorong perkembangan fisik seperti perosotan, papan jungkat jungkit, ayunan, sepeda dibandingkan permainan yang mendorong kemampuan anak bersosialisasi dan kemandirian serta bicara \& bahasa.

Prevalensi penelitian pembelajaran berbasis permainan umum telah tumbuh secara signifikan dalam dekade terakhir. Pertumbuhan ini sebagian karena meningkatnya keakraban dan akses ke permainan hiburan. Pertumbuhan yang berkelanjutan ini telah menyebabkan lebih dari 67\% rumah tangga AS bermain video game secara teratur (Entertainment Software Association, 2013). Namun, prevalensi penelitian tentang desain dan efektivitas permainan edukatif tidak seragam di semua sektor dan kelompok umur. Secara khusus masih kurangnya penelitian tentang permainan edukasi untuk anak usia dini (Pierce, 2013).

Beberapa penelitian terkait, Sylva, Melhuish, Sammons, Siraj-Blatchford \& Taggart (2004), dalam sebuah studi kohort terhadap 3.000 anak di Inggris, menunjukkan bahwa pengalaman prasekolah berbasis bermain yang diperluas (yaitu 3 tahun) menguntungkan bagi anak-anak dari rumah tangga yang kurang beruntung dalam kaitannya dengan pengembangan akademik dan social. Whitebread (2010) mengkaji berbagai studi, termasuk studi observasional anak usia 35 tahun di 32 pengaturan prasekolah, memberikan bukti bahwa perilaku pengaturan diri paling umum diamati pada anak-anak selama bermain kolaboratif, bermain anak-anak (David Whitebread \& Dave Neale, 2017).

\section{SIMPULAN}

Ada hubungan yang signifikan antara jenis stimulasi permainan dan perkembangan balita dengan $p$ value 0,035 , Alat permainan yang disarankan sesuai usia untuk perkembangan anak merupakan alat permainan edukatif, yaitu permainan yang dapat mengoptimalkan perkembangan anak, disesuaikan dengan tingkat perkembangannya.

\section{DAFTAR PUSTAKA}

Ajzen, I. and Fishbein, M. 2005. The influence of attitudes on behavior. In Albarracin, D., Johnson, BT., Zanna MP. (Eds), The handbook of attitudes, Lawrence Erlbaum Assocciates

David Whitebread \& Dave Neale (2017) The role of play in children's development: a review of The Evidence, The Lego Foundation, ISBN: 978-87999589-3-1

Entertainment Software Association (2013) Essential Facts about The Computer and Video Game Industry

Jones, T. L., \& Prinz, R. J. (2005). Potential Roles of Parental Self-Efficacy in Parent and Child Adjustment: A Review. Clinical Psychology 
Gusti Lestari Handayani dan Abbasiah, Hubungan Stimulasi Bermain, Faktor Keluarga dan Faktor Anak dengan Perkembangan Balita di Wilayah Kerja Puskesmas Aur Duri Kota Jambi

Review, 25, 341-363.

http://dx.doi.org/10.1016/j.cpr.2004.12.004

Jean Piaget, 2002. Tingkat Perkembangan Kognitif. Jakarta, Gramedia.

Kementerian Kesehatan RI (2016). Stimulasi, Deteksi dan Intervensi Dini Tumbuh Kembang Anak, FK UI

Pierce (2013) Digital Game-based Learning for Early Childhood, Learnovate Centre, Irland

Sylva, Melhuish, Sammons, Siraj-Blatchford \& Taggart (2004) The Effective Provision of Pre-school Education (EPPE) Project: Findingsfrom preschool to end of key stage 1. Nottingham, UnitedKingdom: Department for Education and Skills.

Soetjiningsih (2005), Tumbuh Kembang Anak, EGC, Jakarta.

Tanuwijaya, S. 2003. Konsep Umum Tumbuh dan Kembang, EGC, Jakarta

Whitebread (2010) The role of parenting in children's self-regulated learning. journal homepage: www.elsevier.com/locate/EDUREV

Wong.Whalley.(2005).Manual of Pediatric Nursing.Philadelphia.Mosby Company 